Marcin Lysko

Uniwersytet w Białymstoku e-mail: marcin.lysko@uwb.edu.pl telefon: +48 857457153

DOI: $10.15290 /$ mhi.2015.14.01.23

\title{
Udział kobiet w życiu publicznym II Rzeczypospolitej Polskiej
}

\section{SUMMARY \\ Women's Participation in the Public Life of the Second Polish Republic}

The Second Polish Republic, which came into being in November 1918, adopted the legislation of the partitioning states which deprived women of the right to participate in public life. Alongside with regaining independence, women obtained full election rights and had their representatives in all parliaments of inter-war Poland. The principle of gender equality was raised to the constitutional level by the Basic Law (Constitution) passed in 1921. In the following years of the inter-war period, women obtained the possibility to be employed as civil servants, barristers, judges and prosecutors.

In spite of the formal equality, public authorities avoided appointing women to more important posts and tolerated practices which were in breach of the Constitution and aimed at limiting the participation of women in public life. The lack of an organ appointed to inspect the compatibility of bills with the constitution and weakness of women's communities was obviously conducive to this process. The full realisation of the gender equality principle, both in the field of legislation and the practice of everyday life, would take place after the Second World War.

Key words: Second Polish Republic, women, public life, public rights

Słowa kluczowe: II Rzeczypospolita, kobiety, życie publiczne, prawa publiczne

Niniejszy artykuł porusza zagadnienie udziału kobiet w życiu publicznym II Rzeczypospolitej w kontekście analizy podstawowych aktów prawnych przyznających kobietom prawa publiczne oraz praktycznej ich realizacji. Z szeregu wątków badawczych składających się na całokształt tej problematyki przedsta-

1 Projekt został sfinansowany ze środków Narodowego Centrum Nauki jako projekt badawczy własny nr NN110189540. 
wiono kwestie praw wyborczych kobiet, ich dostępu do stanowisk publicznych oraz udziału w wymiarze sprawiedliwości, które zdaniem autora najpełniej oddają zachodzący w Polsce międzywojennej proces stopniowego zrównywania praw kobiet i mężczyzn.

Obowiązujące w początkach niepodległości ustawodawstwa byłych państw zaborczych konsekwentnie pozbawiały kobiety praw politycznych, wskutek czego nie uczestniczyły one $\mathrm{w}$ wyborach do organów przedstawicielskich i nie piastowały stanowisk $\mathrm{w}$ aparacie państwowym. W praktyce kobiety dopuszczono jedynie do pełnienia funkcji nauczycielskich oraz do obejmowania niektórych stanowisk w urzędach pocztowych i innych instytucjach publicznych. Nawet jeżeli nie istniały oficjalne zakazy udziału kobiet $\mathrm{w}$ niektórych sferach życia publicznego, to wobec ograniczonego dostępu dziewcząt do edukacji występowały utrudnienia natury praktycznej spowodowane brakiem kwalifikacji niezbędnych do zajmowania stanowisk publicznych².

Z chwilą powstania II Rzeczypospolitej kwestia równouprawnienia kobiet została podniesiona do rangi prawnoustrojowej. Wszystkie główne nurty polityczne oraz tworzone w latach 1918 i 1919 organy kolegialne zgodnie opowiadały się za likwidacją praw dyskryminujących kobiety. Praktyczna realizacja tego postulatu stwarzała duże trudności wobec niemożności uchylenia jednym aktem ustawodawczym wszystkich ograniczeń praw kobiet przejętych w spadku po okresie zaborów. Dotychczasowe regulacje należało bowiem stopniowo zastąpić przepisami dostosowanymi do poszczególnych działów prawa, co wiązało się ze stopniowym opracowywaniem odpowiednich ustaw nowelizujących obowiązujące ustawodawstwo. Natomiast przy tworzeniu aktów normatywnych regulujących od podstaw określone dziedziny życia publicznego czy prywatnego, zasada równouprawnienia kobiet i mężczyzn stała się obowiązującą wytyczną działania organów władzy ustawodawczej³.

\section{Prawa wyborcze kobiet}

Wydarzeniem o znaczeniu przełomowym i zarazem punktem wyjścia działań zmierzających do ukształtowania w II RP pozycji prawnej kobiet na równi z mężczyznami było przyznanie im pełni praw wyborczych na mocy dekretu Naczelnika Państwa z dnia 28 listopada 1918 r. Zawarta w dekrecie ordynacja wyborcza do Sejmu Ustawodawczego ${ }^{4}$ przyznawała czynne prawo wyborcze

2 M. Pietrzak, Sytuacja prawna kobiet w Drugiej Rzeczypospolitej, [w:] Równe prawa i nierówne szanse. Kobiety w Polsce międzywojennej, red. A. Żarnowska, A. Szwarc, Warszawa 2000, s. 78.

3 Ibidem.

4 Dekret z dnia 28 listopada 1918 r. o ordynacji wyborczej do Sejmu Ustawodawczego (Dziennik Praw Państwa Polskiego - Dz. P. P. P. - Nr 18 z 6 XII 1918 r.). 
wszystkim obywatelom bez względu na płeć, narodowość i wyznanie, którzy w dniu wyborów ukończyli 21 lat $^{5}$. Na podobnych zasadach oparto bierne prawo wyborcze, gdyż prawo kandydowania przysługiwało wszystkim obywatelom posiadającym czynne prawo wyborcze, aczkolwiek dopiero po ukończeniu 25 roku życia. Przyznając kobietom pełnię praw wyborczych, Polska dołączyła do stosunkowo nielicznej grupy państw europejskich, w których kobiety mogły uczestniczyć $\mathrm{w}$ życiu politycznym na równi $\mathrm{z}$ mężczyznami ${ }^{6}$. Prekursorem w tej dziedzinie była Finlandia, gdzie kobiety otrzymały prawa wyborcze w 1906, następnie uczyniła to Norwegia w 1913, Dania w 1915, zaś w 1917 prawa wyborcze przyznały kobietom Holandia i Rosja Radziecka7. Daleko w tyle za Polską pozostały kraje uważane za prekursorów ustroju demokratycznego na kontynencie europejskim: Wielka Brytania, w której kobiety otrzymały pełnię praw wyborczych w 1928 r. i Francja, gdzie miało to miejsce dopiero w 1945 r. Zdecydowanym outsiderem w tej grupie była ultrademokratyczna Szwajcaria, gdyż całkowite zrównanie praw wyborczych kobiet i mężczyzn we wszystkich kantonach tego federalnego kraju nastąpiło dopiero $\mathrm{w} 1971 \mathrm{r} .^{8}$

$\mathrm{O}$ ile $\mathrm{w}$ innych krajach przyznanie kobietom praw wyborczych poprzedzała długotrwała walka środowisk feministycznych dążących do emancypacji kobiet, o tyle zrównanie praw politycznych kobiet polskich z mężczyznami nie napotkało większych protestów. Społeczne przyzwolenie dla takiego rozwiązania wynikało $\mathrm{z}$ uznania dla szerokiego udziału kobiet $\mathrm{w}$ konspiracji politycznej okresu zaborów oraz zasług poniesionych $\mathrm{w}$ walkach o niepodległość Polski prowadzonych podczas I wojny światowej i bezpośrednio po jej zakończeniu9.

Zajmując przychylne kobietom stanowisko, najważniejsze ugrupowania polityczne liczyły na głosy żeńskiego elektoratu, który na niektórych terenach znacznie przeważał nad elektoratem męskim. Kobiecy elektorat był atrakcyjniejszy dla partii politycznych z uwagi na przymusowe wywózki części mężczyzn do pracy w Niemczech oraz odbywanie przez nich służby w odradzającym się wojsku polskim, co wykluczało możliwość udziału w wyborach z uwagi na wprowadzony ordynacją wybroczą do Sejmu Ustawodawczego

5 Art. 1 dekretu stanowił, iż „Wyborcą do Sejmu jest każdy obywatel bez różnicy płci, który do dnia ogłoszenia wyborów ukończył 21 lat".

6 L. Hass, Aktywność wyborcza kobiet w pierwszym dziesięcioleciu Drugiej Rzeczypospolitej, [w:] Kobieta $i$ świat polityki, red. A. Żarnowska, A. Szwarc, Warszawa 1996, s. 73.

7 R. Ludwikowski, Prawo konstytucyjne porównawcze, Toruń 2000, s. 450-452.

8 A. Tarnowska, Narodziny trzeciej "płci”. Kobieta w prawie publicznym II RP, [w:] Płeć w życiu publicznym, red. M. Jeziński, M. Wincławska, B. Brodzińska, Toruń 2009, s. 199-200.

9 Jako przykład może posłużyć bohaterski udział Ochotniczej Legii Kobiet w obronie Lwowa. A. Nowak, M. Wójcik, Kobieta w rodzinie w II Rzeczypospolitej, Katowice 2000, s. 53-56. 
zakaz głosowania dla wojskowych w służbie czynnej ${ }^{10}$. Podkreślanie przez główne siły polityczne potrzeby likwidacji przejawów dyskryminacji obywateli z uwagi na płeć wychodziło naprzeciw postulatom środowisk kobiecych, które pomimo braku silnego i zorganizowanego ruchu feministycznego na ziemiach polskich doby zaborów, w końcowych latach I wojny światowej coraz głośniej domagały się przyznania im pełni praw politycznych $\mathrm{w}$ przyszłym państwie polskim ${ }^{11}$. Przemiany kulturowe, jakie zaszły $\mathrm{w}$ Polsce $\mathrm{w}$ rezultacie I wojny światowej przyczyniły się do wzrostu aktywności kobiet w życiu społecznym i politycznym, lecz fakt ten nie spotkał się z przychylnym przyjęciem ze strony polskich elit politycznych. Nad wyobrażeniami czołowych postaci życia publicznego początków II Rzeczypospolitej ciążył stereotyp kobiety wykonującej obowiązki domowe, przypisujący jej tradycyjną rolę matki i żony. Zdecydowanym przeciwnikiem udziału kobiet w życiu politycznym był Roman Dmow$\mathrm{ski}^{12}$, którego konserwatywne nastawienie wyrażało się $\mathrm{w}$ negowaniu podejmowania przez kobiety wyższych studiów czy pracy zarobkowej z uwagi na fakt, iż umysłowość kobiety „zupełnie inna jest od umysłowości mężczyzny"13. Z kolei Józef Piłsudski nie kwestionował potrzeby wprowadzenia zasady równouprawnienia kobiet, lecz wyrażał obawę, czy panie będą umiały rozsądnie wykorzystać przyznane im prawa ${ }^{14}$. Okazję do sprawdzenia, czy społeczeństwo zaakceptowało nową rolę kobiet jako uczestniczek życia publicznego stwarzały zaplanowane na koniec stycznia 1919 r. wybory do Sejmu Ustawodawczego.

Zasada równych praw wyborczych została potwierdzona w Konstytucji marcowej ${ }^{15}$, która przyznawała kobietom czynne i bierne prawo wyborcze do Sejmu oraz Senatu. Regulacje dotyczące warunków uczestnictwa w wyborach do Sejmu ukształtowano analogicznie jak w dekrecie Naczelnika Państwa ${ }^{16}$. Ustawa zasadnicza proklamowała zasadę równouprawnienia wszystkich obywateli Rzeczypospolitej ${ }^{17}$, stąd w świetle jej postanowień pozycja prawna kobiety nie różniła się niczym od pozycji mężczyzny. Uchwalona w okresie auto-

10 M. Niewiadomska-Cudak, Kobiety w polskich organach kolegialnych w latach 1919-2011, Toruń 2013, s. 63-64.

11 D. Kałwa, Kobieta aktywna w Polsce międzywojennej. Dylematy środowisk kobiecych, Kraków 2001, s. 26-27.

12 Podczas rozmowy z Izabelą Lutostańską, jedną z głównych organizatorek utworzonej w $1919 \mathrm{r}$. Narodowej Organizacji Kobiet, Dmowski powiedział „.... jak mi się zaczniesz mieszać do polityki, to będziesz dziwadłem, wiedźmą i nie wyjdziesz nigdy za mąż!", cyt. za: R. Wapiński, Kobiety i życie publiczne - przemiany pokoleniowe, [w:] Równe prawa..., s. 32.

Cyt. za A. Chojnowski, Aktywność kobiet w życiu politycznym, [w:] ibidem, s. 38.

14 Piłsudski wyrażał przekonanie, iż „mentalność kobiety jest z natury konserwatywna i łatwo na nie wpłynąć". A. Piłsudska, Wyznania gorszycielki, oprac. A. Tuszyńska, Warszawa 1992, s. 141. Ustawa z dnia 17 marca 1921 r. Konstytucja Rzeczypospolitej Polskiej (Dz. U. Nr 44, 267).

16 Historia państwa i prawa polskiego, red. P. Bardach, B. Leśnodorski, M. Pietrzak, Warszawa 1996, s. $482-483$.

17 Art. 96 Konstytucji marcowej stanowił, że „Wszyscy obywatele są równi wobec prawa”. 
rytarnych rządów sanacji Konstytucja kwietniowa ${ }^{18}$ nie deklarowała wprost równości wobec prawa, lecz można było ją stworzyć w drodze rozszerzającej wykładni przepisu wprowadzającego niedemokratyczną zasadę elitaryzmu. Mierzone wartością wysiłku i zasług obywatela na rzecz państwa uprawienia do wpływania na sprawy publiczne nie mogły być ograniczane ze względu na pochodzenie, wyznanie, narodowość ani płeć. Konstytucja kwietniowa respektowała także zasadę równych praw wyborczych kobiet i mężczyzn. Wzorem poprzedniczki, ustawa zasadnicza z 1935 r. przyznawała zatem kobietom pełnię praw publicznych, co spotkało się z niemal powszechną aprobatą społeczeństwa ${ }^{19}$.

Zasada równych praw wyborczych kobiet i mężczyzn przez długi czas nie była $w$ pełni realizowana $w$ wyborach do organów samorządu terytorialnego. Wydawane w pierwszych miesiącach niepodległości dekrety Naczelnika Państwa ${ }^{20}$, które przyznawały kobietom pełnię praw wyborczych obowiązywały tylko na obszarze Królestwa Polskiego ${ }^{21}$. Dopiero z biegiem czasu ich moc obowiązującą rozszerzano na wschodnie województwa II RP, podczas gdy w pozostałych częściach kraju utrzymano w mocy przepisy, które obowiązywały w zaborze pruskim i austriackim ${ }^{22}$. Wprawdzie na terenie południowej i zachodniej Polski prawo wyborcze obejmowało wszystkie warstwy społeczne, lecz nie przysługiwało bezpośrednio kobietom. Prawo głosu w sprawach lokalnych pozostało związane z własnością ziemi, która w przeważającej większości przypadków należała do mężczyzny. Nawet jeżeli kobieta była właścicielką ziemi, to $\mathrm{w}$ wyborach samorządowych nie występowała samodzielnie, lecz przez swojego pełnomocnika płci męskiej ${ }^{23}$. Kres obowiązywaniu dyskryminujących kobiety przepisów byłych państw zaborczych położyła przeprowadzona w 1933 r. na mocy tzw. "ustawy scaleniowej” reforma samorządowa ${ }^{24}$. W ramach ujednolicenia ustroju samorządu terytorialnego na terenie całego kraju

18 Ustawa konstytucyjna z dnia 23 kwietnia 1935 r. (Dz. U. Nr 30, poz. 227).

19 S. Krukowski, Konstytucja Rzeczypospolitej Polskiej z 1921 r., [w:] Konstytucje Polski. Studia monograficzne z dziejów polskiego konstytucjonalizmu, red. M. Kallas, Warszawa 1990, s. 173.

20 Podstawę funkcjonowania samorządu terytorialnego w początkach II RP stanowiły dwa dekrety Naczelnika Państwa: o wyborach do rad miejskich na terenie dawnego Królestwa Kongresowego z 18 grudnia 1918 r. (Dziennik Praw Państwa Polskiego 1918, Nr 20, poz. 58) oraz o samorządzie miejskim z 14 lutego 1919 r. (Dziennik Praw Państwa Polskiego 1919, Nr 13, poz. 140).

Czynne prawo wyborcze przysługiwało wszystkim obywatelom bez różnicy płci, którzy ukończyli 21 lat, posiadali polską przynależność państwową i zamieszkiwali na terenie miasta co najmniej 6 miesięcy. Bierne prawo wyborcze posiadały osoby mające prawo czynne, ukończone 25 lat, umiejące pisać i czytać po polsku. G. Łuszkiewicz, Kobiety w samorządzie miejskim drugiej Rzeczypospolitej. Próba portretu zbiorowego, [w:] Kobieta i świat polityki..., s. 119.

M. Niewiadomska-Cudak, op. cit., s. 85.

23 A. Tarnowska, op. cit., s. 199-200.

24 Ustawa z dnia 23 marca 1933 r. o częściowej zmianie ustroju samorządu terytorialnego (Dz. U. Nr 35, poz. 294). 
wprowadzono prawo wyborcze oparte na zasadzie całkowitego równouprawnienia płci $^{25}$. Pomimo to $\mathrm{w}$ poszczególnych kampaniach wyborczych udział kobiet wśród ogółu kandydujących nie przekraczał 10\%, co stanowiło konsekwencję zdominowania list wyborczych przez mężczyzn. Poza znanymi i popularnymi działaczkami określonych partii kobiety były umieszczane przez sztaby wyborcze na dalszych, często ostatnich miejscach list, co z góry przesądzało o ich przegranejej. W skali krajowej kobiety zdobywały niewielką część mandatów w organach uchwałodawczych samorządu terytorialnego. Wyjątkiem były niektóre duże miasta, gdzie kobiety stanowiły nawet 10\% ogólnej liczby radnych. Wysoki na tle średniej krajowej był m.in. udział kobiet $\mathrm{w}$ pracach Rady Miejskiej Warszawy w 1927 r., co tłumaczono faktem większej koncentracji w stolicy kobiet ze średnim i wyższym wykształceniem oraz z większym doświadczeniem i zaangażowaniem z sprawy publiczne ${ }^{27}$.

Z chwilą otrzymania praw politycznych kobiety przejawiały dużą aktywność w kolejnych wyborach parlamentarnych, a skala ich zaangażowania wyborczego nie odbiegała od średniej ogólnokrajowej frekwencji wyborczej. W pierwszych wyborach parlamentarnych, które odbyły się w 1919 r. kobiety stanowiły nawet większość uprawnionych do głosowania, gdyż wskutek udziału mężczyzn $\mathrm{w}$ walkach o ustalenie granic niepodległego państwa polskiego elektorat kobiecy liczebnie przewyższał elektorat męski ${ }^{28}$. Jednak po początkowej euforii spowodowanej uzyskaniem pełni praw wyborczych wśród kobiet, nastąpiło znacznie większe niż wśród mężczyzn rozczarowanie wobec demokratycznych metod wyłaniania władzy. Przyczyną tego były częste zmiany rządów spowodowane brakiem stabilnej większości sejmowej w pierwszych polskich parlamentach. W kolejnych wyborach sejmowych, które miały miejsce w 1922 i 1928 r. frekwencja wyborcza mężczyzn wzrastała, w przeciwieństwie do wykazującej tendencję spadkową frekwencji kobiet ${ }^{29}$.

Wprawdzie przez cały okres międzywojenny kobiety aktywnie korzystały z czynnego prawa wyborczego, lecz większość z nich nie uczestniczyła w kampaniach wyborczych. Aktywność polityczna kobiet w Polsce międzywojennej była stosunkowo niewielka, na co wskazuje liczba zdobywanych przez nie man-

25 W porównaniu w dekretami Naczelnika Państwa tzw. „ustawa scaleniowa” wprowadziła podwyższony cenzus wieku. Czynne prawo wyborcze przysługiwało osobom, które ukończyły 24 lata, a bierne pod ukończeniu 30 lat. M. Niewiadowska-Cudak, op. cit., s. 87.

G. Łuszkiewicz, op. cit., s. 121 M. Pietrzak, op. cit., s. 79

Jako przykład mogą posłużyć dane z trzech największych polskich miast, w których w $1919 \mathrm{r}$. odbyły się wybory do Sejmu Ustawodawczego. W Warszawie kobiety stanowiły $58 \%$ uprawnionych do głosowania, w Łodzi 56\%, natomiast w Krakowie 57\%. M. Śliwa, Udział kobiet w wyborach $i$ ich działalność parlamentarna, [w:] Równe prawa..., s. 50.

29 L. Hass, Aktywność wyborcza kobiet w pierwszym dziesięcioleciu Drugiej Rzeczypospolitej, [w:] Kobieta i świat..., s. 98-99. 
datów parlamentarnych. Udział kobiet w obydwu izbach polskiego parlamentu pozostawał przez cały okres międzywojenny bardzo skromny, gdyż łącznie piastowały one 41 mandatów poselskich i 20 senatorskich ${ }^{30}$. Faktycznie jednak były 32 posłanki i 18 senatorek, gdyż niektóre z nich wielokrotnie pełniły mandaty $\mathrm{w}$ obu izbach parlamentarnych ${ }^{31}$. Kobieca reprezentacja w poszczególnych parlamentach II Rzeczypospolitej stanowiła zaledwie od 2 do 4\% ogólnej liczby posłów i senatorów ${ }^{32}$, lecz na tle męskiej większości parlamentarna frakcja kobiet wyróżniała się pochodzeniem społecznym, wykształceniem i pozycją zawodową. Niemal wszystkie międzywojenne parlamentarzystki pochodziły $\mathrm{z}$ rodzin inteligenckich lub ziemiańskich, przy czym większość z nich posiadała wykształcenie wyższe uniwersyteckie, a kilka zdobyło nawet dyplomy doktorskie. Pozostałe ukończyły szkoły średnie lub półwyższe, wyjątkiem była zasiadająca w Sejmie III kadencji (1930-1935) posłanka frakcji komunistycznej, która jako robotnica legitymowała się zaledwie wykształceniem podstawowym ${ }^{33}$.

Przyczyn tak skromnego udziału kobiet w parlamencie należy upatrywać, po pierwsze, w braku dostatecznej aktywności politycznej środowisk kobiecych, które nie potrafiły się należycie zorganizować, aby w pełni wykorzystać fakt przyznania kobietom pełni praw politycznych. Kobiety zachowywały się biernie wobec przejawów życia politycznego, gdyż nie zdawały sobie sprawy z wagi praw wyborczych, należących jednocześnie do najważniejszych obowiązków obywatelskich. Kobiety nie popierały w dostatecznym stopniu kandydatur kobiecych $\mathrm{w}$ wyborach parlamentarnych, gdyż nie do końca zdawały sobie sprawę $\mathrm{z}$ roli, jaką $\mathrm{w}$ walce o faktyczne równouprawnienie płci odgrywały polskie parlamentarzystki. Nawet tworzone w Polsce międzywojennej liczne organizacje kobiece koncentrowały się nie tyle na problemach życia politycznego, co zajmowały się przede wszystkim sprawami dotyczącymi podnoszenia statusu materialnego kobiet, pobudzania ich aspiracji zawodowych, intelektualnych oraz upowszechnieniem przekonania o równorzędnej pozycji kobiety względem mężczyzny ${ }^{34}$.

$$
\text { m }
$$

32 W Sejmach czterech kolejnych kadencji (1919-1935) zasiadała Gabriela Balicka (wdowa po Zyg-
muncie Balickim, jednym z przywódców ruchu narodowo-demokratycznego), a przez trzy kaden-
cje mandat poselski piastowały Irena Kosmowska (1919-1930), Zofia Praussowa (1922-1930) oraz W Sejmach czterech kolejnych kadencji (1919-1935) zasiadała Gabriela Balicka (wdowa po Zyg-
muncie Balickim, jednym z przywódców ruchu narodowo-demokratycznego), a przez trzy kaden-
cje mandat poselski piastowały Irena Kosmowska (1919-1930), Zofia Praussowa (1922-1930) oraz oraz 1930-1936). M. Śliwa, Kobiety w parlamencie Drugiej RzeczypoW poszczególnych kadencjach parlamentu stan reprezentacji kobiecej przedstawiał się następująco: W Sejmie Ustawodawczym - 6 mandatów (1,38 ogólnej liczy posłów), w Sejmie i Senacie I kadencji - odpowiednio $9(2,02 \%)$ oraz $4(3,60 \%)$, Sejmie i Senacie II kadencji - $8(1,80 \%)$ i $4(3,60 \%)$, Sejmie i Senacie III kadencji - $15(3,37 \%)$ i $4(3,60 \%)$, Sejmie i Senacie IV kadencji - $2(0,97 \%)$ oraz $5(5,20 \%)$, a w ostatniej V kadencji - $1(0,48 \%)$ i 4 (4,16\%). M. Śliwa, Udział kobiet..., s. 53.

33 M. Podkowski, Udział kobiet w parlamentach Drugiej Rzeczypospolitej, [w:] Pozycja prawna kobiet w dziejach, red. S. Rogowski, Wrocław 2010, s. 163.

34 A. Chojnowski, Kobiety i polityka w Drugiej Rzeczypospolitej, [w:] Kobieta i świat..., s. 12-13. 
Kolejnym powodem znikomej obecności kobiet w polskim parlamencie był niechętny stosunek mężczyzn do aktywności politycznej kobiet oraz chęć zachowania sobie wysokich stanowisk. Zdominowane przez mężczyzn partie polityczne bardzo liczyły na poparcie kobiecego elektoratu w wyborach parlamentarnych, lecz same bardzo niechętnie widziały kobiety $\mathrm{w}$ roli parlamentarzystek i z oporami udostępniały im miejsca na swoich listach wyborczych. Wyrazem lekceważącego stosunku względem kobiet pretendujących do roli parlamentarzystek było umieszczanie ich nazwisk na ostatnich miejscach list kandydatów, co wobec głosowania na listy wyborcze z góry skazywało kobiecie kandydatki na przegraną.

W kwestii dopuszczenia kobiet do udziału w życiu politycznym mężczyźni wykazywali się wyjątkową solidarnością. Niechętna kobietom postawa cechowała nie tylko partie prawicowe, reprezentujące bardzo tradycyjny pogląd na rolę kobiety $\mathrm{w}$ społeczeństwie, lecz także szeroko wykorzystujące podczas kampanii wyborczych hasła feministyczne partie lewicowe. Stąd udział kobiet na listach wyborczych do kolejnych parlamentów II Rzeczypospolitej kształtował się na poziomie ok. $2 \%$ ogólnej liczby kandydatów. Nieczęsto miały miejsce takie sytuacje, jak wystawienie przez rządzący obóz sanacyjny większej liczby kandydatek niż pozostałe ugrupowania $\mathrm{w}$ wyborach parlamentarnych 1930 r., dokonane pod wpływem nacisków ze strony silnego lobby kobiecego ${ }^{35}$. W konsekwencji udział kobiet w wybranym wówczas Sejmie III kadencji osiągnął najwyższy w Polsce międzywojennej wskaźnik 3,1\% ogólnej liczby posłów. W kolejnych wyborach środowiska feministyczne nie potrafiły już tak skutecznie lobować na rzecz swoich interesów, wskutek czego kobiety stanowiły zaledwie 0,9\% ogólnej liczby posłów w Sejmie IV kadencji (wybory z 1935 r.) oraz $0,4 \%$ w ostatnim Sejmie II Rzeczypospolitej, do którego wybory miały miejsce w $1938 \mathrm{r}^{36}$

Wprawdzie kobiety posiadały skromną reprezentację parlamentarną, lecz pomimo to przyczyniły się do rozwoju demokratycznego ustawodawstwa, demokratyzacji szkolnictwa i całego systemu edukacji, rozwoju opieki nad dzieckiem i matką, czy też poprawy sytuacji prawnej i społecznej kobiet. Na większości posiedzeń Sejmu i Senatu poruszały zagadnienia dotyczące równouprawnienia kobiet $\mathrm{w}$ dziedzinie prawa do nauki, do pracy, równej płacy za jednakową pracę, czy zajmowania przez kobiety odpowiednich stanowisk $\mathrm{w}$ urzędach. $\mathrm{W}$ zakresie praw cywilnych kobiety wysuwały postulaty zniesienia ograniczeń $\mathrm{w}$ prawie majątkowym oraz przyznania kobiecie prawa swobodnego wyboru jej obywatelstwa $\mathrm{w}$ wypadku małżeństwa $\mathrm{z}$ cudzoziemcem lub zmiany obywatelstwa przez męża. W swojej pracy kierowały się troską

35 A. Chojnowski, Moralność i polityka. Kobiece lobby w Bezpartyjnym Bloku Wspótpracy z Rządem, [w:] Kobieta $i$ świat..., s. 166.

36 M. Podkowski, op. cit., s. 161. 
o dobro społeczeństwa i państwa, reprezentując przy tym wysoką kulturę polityczną i tworząc nieosiągalny dla wielu posłów wzór postawy i zachowania parlamentarzysty ${ }^{37}$.

Kobiety - parlamentarzystki wnosiły i referowały projekty ustaw dotyczące spraw kobiet, przyczyniając się do uchwalenia kilku ważnych aktów prawnych, chroniących interesy kobiet oraz poprawiających ich pozycję prawną. Przykładowo w 1919 r. roku z inicjatywy posłanek Sejm Ustawodawczy przyjął ustawę o sprzedaży i wyrobie spirytusu i napojów alkoholowych ${ }^{38}$, która wywołała zainteresowanie w innych krajach europejskich. Przedstawicielka frakcji kobiecej wniosła pod obrady Sejmu Ustawodawczego uchwaloną w 1921 r. ustawę $\mathrm{w}$ przedmiocie zmiany niektórych przepisów prawa cywilnego dotyczących kobiet $^{39}$, a w 1924 r. posłanki walnie przyczyniły się do uchwalenia ustaw dotyczących zwalczania handlu kobietami i dziećmi oraz ochrony kobiet i młodocianych $w$ prawie pracy ${ }^{40}$.

\section{Dostęp kobiet do stanowisk publicznych}

Konsekwencją podniesienia do rangi konstytucyjnej zasady równouprawnienia wszystkich obywateli bez względu na płeć było dopuszczenie kobiet do zajmowania stanowisk publicznych na równi z mężczyznami. Konstytucja marcowa przewidywała, iż „urzędy publiczne są $\mathrm{w}$ równej mierze dla wszystkich dostępne na warunkach prawem przypisanych". Warunki wymagane od kandydatów na urzędy i stanowiska publiczne określić miały ustawy, które wobec zakazu dyskryminacji z uwagi na płeć miały uwzględniać takie kryteria jak wiek, wykształcenie oraz kwalifikacje zawodowe. Najważniejszym z nich była regulująca stosunki pracy $\mathrm{w}$ administracji państwowej ustawa $\mathrm{z}$ dnia 17 lutego 1922 r. o państwowej służbie cywilnej ${ }^{41}$. Oceniana jako postępowa i zawierająca szereg ważnych gwarancji dla urzędników i niższych funkcjonariuszy państwowych ustawa formalnie nie różnicowała urzędników ze względu

37 M. Śliwa, Kobiety w parlamencie..., s. 68-69.

38 Posłanka Zofia Moraczewska żądała wprowadzenia do ustawy przepisu zakazującego sprzedaży i spożywania alkoholu w wojsku oraz w czasie świąt państwowych i religijnych. Sprawozdanie stenograficzne z 138 posiedzenia Sejmu Ustawodawczego w dniu 20 kwietnia $1920 \mathrm{r}$.

39 Referująca projekt ustawy Gabriela Balicka starała się przekonać posłów, iż kobieta zamężna powinna być równouprawniona $\mathrm{z}$ mężczyzną $\mathrm{w}$ dziedzinie działań prawnych, piastowania urzędów i stanowisk publicznych, dysponowania majątkiem, korzystania z praw rodzicielskich. Ustawa z dnia 1 lipca 1921 r. zmieniła odziedziczone po okresie zaborów przepisy prawa cywilnego dotyczące kobiet. Uchylono m.in. przepis nakazujący żonie posłuszeństwo mężowi oraz zniesiono ograniczenia uzależniające wykonywanie wszelkich działań prawnych przez żonę bez zgody męża. M. Śliwa, Kobiety w parlamencie..., s. 59. 
na płeć. W świetle jej postanowień urzędnikiem mógł zostać każdy obywatel polski, spełniający wymagane przez ustawodawcę warunki ${ }^{42}$. Formą ukrytej dyskryminacji był natomiast przewidziany $\mathrm{w}$ ustawie obowiązek przestrzegania przez organy administracji przepisów prawa cywilnego przy przyjmowaniu do służby państwowej kobiet zamężnych ${ }^{43}$. Wynikło to $\mathrm{z}$ tego, iż odziedziczone po zaborcach anachroniczne przepisy wymagały zgody męża na podjęcie pracy przez żonę. Wynikało to $\mathrm{z}$ faktu, iż $\mathrm{w}$ świetle prawa cywilnego to mąż $\mathrm{z}$ reguły ponosił finansową odpowiedzialność za żonę, sprawując także zarząd jej majątkiem przez cały czas trwania małżeństwa. Ponadto, ustawa o państwowej służbie cywilnej przewidywała zakaz pracy małżonków w tym samym urzędzie, na stanowiskach powiązanych ze sobą finansowo ${ }^{44}$. Rozwiązanie to nie miało jednak charakteru dyskryminującego kobiety, gdyż dotyczyło również rodziców i dzieci urzędnika oraz jego rodzeństwa. W żadnym stopniu nie dyskryminowały kobiet przepisy ustawy dotyczące usunięcia urzędnika państwowego, rozwiązania stosunku służbowego, podziału na kategorie służbowe, czy też starszeństwa służbowego ${ }^{45}$.

Pomimo ostrego sprzeciwu środowisk kobiecych nie udało się powstrzymać wprowadzenia w życie na terytorium autonomicznym Górnego Śląska przepisów jawnie dyskryminujących kobiety zamężne. Wzorowane na dawnych przepisach niemieckich rozwiązania zawierała uchwalona przez Sejm Śląski w 1926 r. tzw. ustawa celibatowa ${ }^{46}$, która zezwalała na zatrudnianie w szkolnictwie śląskim wyłącznie kobiet niezamężnych. Ograniczeniem kobiet zamężnych $\mathrm{w}$ zakresie obejmowania stanowisk $\mathrm{w}$ administracji samorządowej województwa śląskiego był wprowadzony w 1934 r. wymóg uzyskania stosownego zezwolenia Śląskiej Rady Wojewódzkiej ${ }^{47}$. Zarówno nauczycieli, jak i funkcjonariuszki zatrudnione na terenie województwa śląskiego traciły swoje stanowisko z chwilą zawarcia związku małżeńskiego. Rozwiązanie stosunku służbowego skutkowało pozbawieniem prawa do emerytury. Zwolniona z pracy mężatka zachowywała jedynie prawo do odprawy ${ }^{48}$.

42 Według art. 6 ustawy „urzędnikiem może być mianowany jedynie obywatel polski, o nieskazitelnej przeszłości, posiadający zdolność do działań prawnych oraz uzdolniony fizycznie i umysłowo do pełnienia odnośnych obowiązków służbowych, tudzież władający biegle językiem polskim w mowie i piśmie".

43 W myśl postanowień art. 6 ustawy „przy przyjmowaniu do służby państwowej osób nieletnich i kobiet zamężnych władza będzie przestrzegać zasad obowiązujących ustaw cywilnych".

44 Art. 10 ustawy o państwowej służbie cywilnej.

45 A. Tarnowska, op. cit., s. 201. Ustawa z dnia 29 marca 1926 r. w sprawie rozwiązania stosunku służby nauczycielskiej wskutek zawarcia przez nauczycielkę związku małżeńskiego (Dziennik Ustaw Śląskich 1926, Nr 8, poz. 12). Ustawą z dnia 22 czerwca 1934 r. o stosunkach służbowych śląskich funkcjonariuszów publicznych (Dziennik Ustaw Śląskich Nr 18, poz. 37). 
Pozostająca $\mathrm{w}$ jawnej sprzeczności z konstytucyjną zasadą równego dostępu kobiet i mężczyzn do stanowisk publicznych ustawa celibatowa została uchwalona przez Sejm Śląski w absurdalnym przekonaniu, iż nie narusza postanowień Konstytucji marcowej, jak też obowiązującej na terenie Górnego Śląska Konwencji genewskiej z 15 maja 1922 r. ${ }^{49}$ Pomimo protestów różnych środowisk opowiadających się za nadaniem kobietom śląskim pełni praw publicznych, ustawa celibatowa została w 1933 r. zatwierdzona przez Prezydenta Rzeczypospolitej50. Prezydent uczynił tak ze względów politycznych, aby zyskać przychylność Ślązaków dla programu rządzącego Polską obozu sanacyjnego. Ustawa celibatowa była traktowana przez ludność Górnego Śląska jako wyraz odrębności szkolnictwa tego terenu, stanowiącego jedyne terytorium autonomiczne $\mathrm{w}$ opartym na jednolitej strukturze podziału terytorialnego państwie polskim. Cofnięcie ustawy celibatowej oznaczałoby wprowadzenie na Górnym Śląsku rozwiązań ogólnopolskich ustaw oświatowych i tym samym utratę ważnego atrybutu autonomii śląskiej. Poza tym, u podstaw uchwalenia ustawy celibatowej legło przywiązanie Górnoślązaków do tradycyjnego postrzegania roli kobiety zamężnej jako żony i matki. Posłowie śląscy głosujący za przyjęciem ustawy celibatowej opowiadali się za patriarchalnym modelem rodziny śląskiej, według którego mąż i ojciec pracowali zawodowo, a żona i matka prowadziła gospodarstwo domowe i zajmowała się wychowywaniem dzieci. Przyjęcie ustawy celibatowej motywowano także względami ekonomicznymi twierdząc, że wychowujące własne dzieci mężatki pozostawały droższą siłą roboczą. Korzystały bowiem częściej z urlopów niż nauczyciele mężczyźni, postrzegani jako głowy rodzin śląskich, stąd zwolnienie z pracy w szkolnictwie kobiet zamężnych miało doprowadzić do uzdrowienia stosunków społecznych ${ }^{51}$.

Po wejściu $\mathrm{w}$ życie ustawy celibatowej zwolniono z pracy wszystkie zamężne nauczycielki zatrudnione krócej niż jeden rok. Pracę utrzymały jedynie te z zamężnych nauczycielek, które legitymowały się pełnymi kwalifikacjami pedagogicznymi i pracowały dłużej niż rok. Niezależnie od kwalifikacji i stażu pracy zwalniano także kobiety, które w czasie pełnienia obowiązków nauczycielskich wstąpiły z związki małżeńskie. W sierpniu 1926 r. ze szkol-

Sprawozdanie stenograficzne z 134 posiedzenia I Sejmu Śląskiego z 29 III 1926, łam 3.

Rozporządzenie Prezydenta Rzeczypospolitej z dnia 28 października 1933 r. w sprawie zmiany ustawy z dnia 1 lipca 1926 r. o stosunkach służbowych nauczycieli i rozporządzenia Prezydenta Rzeczypospolitej Polskiej z dnia 6 marca 1928 r. w sprawie o kwalifikacjach zawodowych nauczycieli szkół powszechnych (Dz. U. Nr 85, poz. 600).

51 Według dostępnych danych obejmujących rok $1935 \mathrm{w}$ szkolnictwie śląskim 38,9\% nauczycieli stanowiły kobiety, co pozwala przypuszczać iż przed uchwaleniem w 1926 r. ustawy celibatowej odsetek ten był jeszcze wyższy. A. Glimos-Nagórska, Tradycjonalizm śląski a równouprawnienie kobiet. Praca zawodowa i życie codzienne nauczycielek województwa śląskiego (1922-1939), [w:] Równe prawa..., s. $158-161$. 
nictwa odeszło z tego powodu około 250 nauczycielek, a w kolejnych latach zwalniano corocznie po kilkadziesiąt nauczycielek, które zmieniły stan cywilny ${ }^{52}$.

Ustawa celibatowa była przedmiotem szeregu rezolucji kierowanych przez organizacje nauczycielskie do centralnych i śląskich władz oświatowych, w których podkreślano, iż wskutek jej uchwalenia głównym kryterium branym pod uwagę przy zatrudnianiu nauczycielek uczyniono stan cywilny. Ponadto, wskazywano na fakt, iż ustawa celibatowa podwójnie karała nauczycielki wychodzące za mąż: po pierwsze, zwolnieniem z pracy, a po drugie, niższą odprawą niż $\mathrm{w}$ przypadku zwolnienia $\mathrm{z}$ pracy $\mathrm{z}$ innych przyczyn niż zawarcie związku małżeńskiego. Śląskie władze oświatowe, które corocznie sporządzały listę nauczycielek podlegających zwolnieniu na mocy ustawy celibatowej pozostawały głuche wobec nasilającej się krytyki ze strony środowisk nauczycielskich i innych postępowych gremiów. Obowiązywaniu sprzecznych z ustawą zasadniczą regulacji sprzyjał fakt braku w Polsce międzywojennej organu zajmującego się badaniem zgodności aktów prawnych z Konstytucją, co sprzyjało takim paradoksom legislacyjnym jak wspomniane zatwierdzenie ustawy celibatowej przez Prezydenta RP z powodów stricte politycznych. Fakt obowiązywania na Górnym Śląsku sprzecznego z Konstytucją prawa dyskryminującego kobiety był stale podkreślany na łamach ukazującej się w II RP prasy kobiecej, a także w szeregu wystąpieniach kobiecych aktywistek na forum publicznym. Wysiłki środowisk kobiecych oraz innych postępowych gremiów przyniosły efekt dopiero po 12 latach, gdyż w 1938 r. Sejm Rzeczypospolitej Polskiej uchylił moc obowiązującą ustawy celibatowej ${ }^{53} \mathrm{w}$ drodze rozciągnięcia na obszar województwa śląskiego przepisów oświatowych obowiązujących w całej Polsce ${ }^{54}$.

Pomimo ograniczeń $\mathrm{w}$ dostępie do stanowisk publicznych kobiety stanowiły $20 \%$ personelu administracji publicznej i były zatrudnione we wszystkich urzędach państwowych i samorządowych. $W$ praktyce zajmowały najniższe stanowiska służbowe i były pozbawione szans awansu zawodowego, o czym świadczy fakt pozostawania około $70-80 \%$ urzędniczek $w$ trzech najniższych stopniach służbowych pod koniec lat dwudziestych XX w. ${ }^{55}$ Sporadycznie kobiety pełniły funkcje urzędników średniego szczebla, pracując na stanowiskach kierowniczych co najwyżej w bibliotekach i sekretariatach. Wobec utrzymującej

52 W. Wanatowicz, Ludność napływowa na Górnym Ślasku w latach 1922-1939, Katowice 1982, s. 116. Ustawą z dnia 9 kwietnia 1938 o zmianie ustawy o stosunkach służbowych nauczycieli (Dz. U. $\mathrm{Nr} 27$, poz. 243).

54 A. Glimos-Nagórska, op. cit., s. 160-161.

55 W 1931 r. w państwowej służbie cywilnej było zatrudnionych 5 tys. kobiet, które były zaszeregowane w grupie uposażenia od VIII do XII. Zaledwie około $200 \mathrm{z}$ nich zdołało uplasować się w niższych grupach uposażenia od IV do VII. Kobiety te stanowiły zaledwie $8 \%$ funkcjonariuszy państwowych w tej grupie uposażania. M. Pietrzak, op. cit., s. 79. 
się w okresie Wielkiego Kryzysu (pierwsza połowa lat trzydziestych) tendencji do stopniowego zmniejszania liczby urzędników, kobiety były masowo zwalniane jako nieposiadające odpowiedniego wykształcenia i kwalifikacji. Wobec niechęci władz państwowych do obsadzania wyższych stanowisk administracyjnych kobietami, w Polsce międzywojennej nie doszło do sytuacji, w której kobieta zostałaby ministrem lub piastowałaby kierownicze stanowiska $\mathrm{w}$ administracji terenowej ${ }^{56}$.

Nawet $\mathrm{w}$ administracji szkolnictwa na szczeblu terenowym, gdzie kobiety stanowiły większość pracowników fachowych, kierownicze stanowiska dyrektorów szkół, inspektorów oraz kuratorów oświaty obsadzano mężczyznami, chociaż niejednokrotnie ich poziom przygotowania fachowego pozostawiał wiele do życzenia. Fakt braku kobiet na wyższych stanowiskach administracyjnych tłumaczono tym, że nie posiadały one kwalifikacji zawodowych oraz nie były przygotowane pod kątem mentalnym do pełnienia odpowiedzialnych funkcji kierowniczych. W międzywojennej Polsce panował negatywny stereotyp kobiety-urzędniczki, jako osoby niedouczonej i niekompetentnej, która koncentrowała się na życiu towarzyskim w miejscu pracy, a nie sumiennym wykonywaniu pracy zawodowej. Powszechnie uważno, że kobiety zawdzięczały posadę urzędniczki koneksjom rodzinnym lub urodzie, a nie kwalifikacjom, przez co odbierały pracę znacznie lepiej przygotowanym pod względem fachowym mężczyznom ${ }^{57}$.

\section{Kobiety w wymiarze sprawiedliwości}

Podobnie jak $\mathrm{w}$ dziedzinie administracji publicznej kobiety miały utrudniony dostęp do pracy w wymiarze sprawiedliwości, gdyż pochodzący z $1919 \mathrm{r}$. dekret $\mathrm{o}$ aplikacji sądowej ${ }^{58}$ przewidywał mianowanie na stanowiska sędziowskie wyłącznie mężczyzn. Dekret ten naruszał konstytucyjną zasadę równouprawnienia mężczyzn i kobiet, lecz po wejściu w życie Konstytucji marcowej nie został uchylony. W myśl jego postanowień kobiety mogły odbywać aplikację sądową tylko jako przygotowanie do zawodu adwokata. Pochodzący z grudnia 1918 r. Tymczasowy Statut Palestry Państwa Polskiego ${ }^{59}$ dopuszczał kobiety do wykonywania zawodu adwokata na równi z mężczyznami, o ile spełniały one

56 J. Żarnowski, Kobiety w strukturze społeczno-zawodowej Polski międzywojennej, [w:] Równe prawa..., s. 104.

57 M. Gawin, Głosy krytyczne w sprawie zawodowej kwestii kobiet 1918-1939, [w:] Kobieta i praca. Wiek XIX $i$ XX, red. A. Żarnowska, A. Szwarc, Warszawa 2000, s. 308-310. Dekret Naczelnika Państwa z dnia 8 lutego 1919 r. o aplikacji sądowej (Dz. Pr. P. P. Nr 18, poz. 225). 
określone warunki ogólne oraz posiadały kwalifikacje zawodowe ${ }^{60}$. Ze względu na konserwatywne poglądy społeczne władz samorządu adwokackiego, absolwentkom wydziałów prawa konsekwentnie odmawiano przyjęcia na aplikację adwokacką. Starająca się o przyjęcie do krakowskiej Izby Adwokackiej pierwsza kobieta z dyplomem Wydziału Prawa Uniwersytetu Jagiellońskiego otrzymała jednoznaczną odpowiedz, że nie przyjmuje się kobiet ${ }^{61}$. Pierwsza kobieta została wpisana na listę adwokatów dopiero w 1925 r. Helena Wiewiórska legitymowała się dyplomem ukończenia studiów prawniczych w Petersburgu, gdzie odbyła także aplikację adwokacką. Fakt ten odnotowało kobiece czasopismo „Bluszcz", jako jeden z przełomowych momentów w walce kobiet o dostęp do wszelkich zawodów i należną im pozycję ${ }^{62}$.

Od tego momentu kobiety zyskały dostęp do kariery adwokackiej i coraz częściej występowały jako obrońcy w procesach sądowych. Do wybuchu II wojny światowej ponad 200 kobiet zostało adwokatami ${ }^{63}$, stąd zawód adwokata był najbardziej sfeminizowaną profesją prawniczą w Polsce międzywojennej. Jednak przeważająca część kobiet po ukończeniu aplikacji sędziowskiej była zmuszona do podjęcia pracy $\mathrm{w}$ administracji, bankach, towarzystwach ubezpieczonych i handlu. $Z$ pracy kobiet $w$ charakterze radców prawnych najczęściej korzystały prywatne przedsiębiorstwa, gdyż świadczone przez nie usługi były znacznie tańsze niż ich kolegów po fachu ${ }^{64}$.

Jeszcze dłużej naporowi ze strony kobiet opierał się wymiar sprawiedliwości, do udziału w którym kobiety zostały oficjalnie dopuszczone dopiero w wyniku przeprowadzonej w 1928 r. unifikacji prawa o ustroju sądów powszechnych ${ }^{65}$. Wśród warunków niezbędnych do objęcia stanowiska sędziego ${ }^{66}$

60 Były to następujące warunki ogólne: obywatelstwo polskie, pełnia praw publicznych, nieskazitelność charakteru oraz biegła znajomość języka polskiego. Jako warunki szczególne przewidziano ukończenie wyższych studiów prawniczych na krajowym uniwersytecie oraz odbycie aplikacji sądowej i adwokackiej, zakończonych zdanym egzaminem. M. Materniak-Pawłowska, Adwokatura w II Rzeczypospolitej. Zagadnienia prawno-ustrojowe, Poznań 2009, s. 159-160.

61 U. Perkowska, Studentki Uniwersytetu Jagiellońskiego w latach 1894-1939, [w:] Kobieta i kultura, red. A. Żarnowska, A. Szwarc, Warszawa 1996, s. 166.

62 M. Kondracka, Kobiety na uniwersytetach, [w:] Równe prawa..., s. 282.

63 Szybki awans kobiet w szeregi adwokatury obrazują dane dotyczące Izby Adwokackiej w Warszawie, gdzie w 1926 r. była tylko 1 adwokatka i 11 aplikantek, w 1930 r. 24 adwokatki i 52 aplikantki, a w 1934 r. 89 adwokatek (na ogólną liczbę 1844 adwokatów) oraz 112 aplikantek (na ogólną liczbę 695 aplikantów). M. Stypułkowska, Trudna droga kobiet do wykonywania zawodów prawniczych, „Palestra" 1994, nr 9-10, s. 141.

65 Rozporządzenie Prezydenta Rzeczypospolitej Polskiej z dnia 6 lutego 1928 r. prawo o ustroju sądów powszechnych (Dz. U. Nr 12, poz. 93)

66 Oprócz posiadania obywatelstwa polskiego od kandydatów na stanowisko sędziego wymagano korzystania z pełni praw publicznych, nieskazitelnego charakteru, władania językiem polskim w mowie i piśmie, ukończenia 25 roku życia, ukończenia uniwersyteckich studiów prawniczych, odbycia aplikacji sądowej oraz zdania egzaminu sędziowskiego. M. Materniak-Pawłowska, Zawód sędziego w Polsce w latach 1918-1939, "Czasopismo Prawno-Historyczne” 2011, nr 1, s. 84. 
znajdował się wymóg posiadania obywatelstwa polskiego bez względu na płeć, chociaż kwestia dopuszczenia kobiet do udziału w sądownictwie budziła duże kontrowersje wśród członków Komisji przygotowującej projekt prawa o ustroju sądów powszechnych. Wobec równości głosów o jej ostatecznym rozstrzygnięciu zdecydował głos przewodniczącego Komisji, którego zdaniem regulacje konstytucyjne nie pozwalają na wyłączenie kobiet od sprawowania urzędu sędziego ${ }^{67}$. Pomimo formalnego dopuszczenia do wykonywania zawodu sędziego kobiet - na takich samych zasadach co mężczyzn - prawo o ustroju sądów powszechnych niespodziewanie wyłączyło kobiety od pełnienia funkcji przysięgłych w sądach zajmujących się sprawami dotyczącymi zbrodni zagrożonych najwyższymi karami. Kobiety postawiono na równi ze skazańcami, upośledzonymi oraz osobami czerpiącymi zyski z nierządu, gdyż te kategorie mężczyzn zostały wyłączone ze sprawowania funkcji przysięgłych. Ta jawna dyskryminacja kobiet stała $\mathrm{w}$ sprzeczności $\mathrm{z}$ konstytucyjną zasadą równouprawnienia płci, przez co stała się obiektem krytyki ze strony organizacji feministycznych. Wprawdzie kierownictwo resortu sprawiedliwości nie zdecydowało się na powołanie do życia sądów przysięgłych, lecz na terenie Polski południowej sądy przysięgłych funkcjonowały bez udziału kobiet na mocy przepisów odziedziczonych po zaborcy austriackim. Dopiero w 1938 r. zlikwidowano ten niechlubny wyjątek od zasady równego dostępu kobiet i mężczyzn do stanowisk sędziowskich, gdyż z przyczyn politycznych władze podjęły decyzje o całkowitej likwidacji sądów przysięgłych ${ }^{68}$.

Chociaż prawo o ustroju sądów powszechnych przewidywało obejmowanie przez kobiety stanowisk sędziowskich oraz prokuratorskich, to w praktyce uzyskanie przez kobietę nominacji sędziowskiej było bardzo trudne i niezwykle rzadkie. Tym niemniej w 1929 r. pierwsza kobieta otrzymała nominacje sędziowską i rozpoczęła pracę $w$ sądzie dla nieletnich w Warszawie. Była nią absolwentka studiów prawniczych w Warszawie Wanda Grabińska, która pełniła funkcję sędziego dla nieletnich tylko przez trzy lata, gdyż w 1932 r. przyjęła stanowisko radcy w Ministerstwie Opieki Społecznej. Szczyciła się tym, że jest trzecią czy czwartą kobietą w Europie wykonującą zawód sędziego ${ }^{69}$. W tymże roku kolejne dwie kobiety otrzymały nominacje sędziowskie i podobnie jak Grabińska zajmowały się sprawami nieletnich, które, zdaniem konserwatywnych władz resortu sprawiedliwości, najbardziej odpowiadały predyspozycjom kobiet $^{70}$. W sprawach osób dorosłych pierwsza kobieta zaczęła orzekać dopiero w 1937 r., przy czym początkowo były to sprawy cywilne, a dopiero rok później

M. Mohyluk, Prawo o ustroju sądów powszechnych w pracach Komisji Kodyfikacyjnej II Rzeczypospolitej, Białystok 2004, s. 145

68 A. Tarnowska, op. cit., s. 201.

Z. Milewski, Zanim kobieta została adwokatem, „Palestra” 2002, nr 1-2, s. 108. 
przekazano jej orzekanie w sprawach karnych ${ }^{71}$. Ze względu na nieprzychylne podejście władz resortu sprawiedliwości do zatrudniania na stanowiskach sędziów kobiet do 1939 r. zaledwie 7 kobiet otrzymało nominacje sędziowskie, a kolejnych 8 pełniło funkcję asesorów sądowych. Kobiety-sędziny orzekały w sądach najniższego szczebla, które zajmowały się rozpatrywaniem drobniejszych spraw karnych i cywilnych oraz sprawami nieletnich ${ }^{72}$.

O ile w II Rzeczypospolitej kobiety powoli zaczęły wkraczać do sądów powszechnych, o tyle żadna z nich nie zdołała uzyskać nominacji prokuratorskiej. W momencie wybuchu II wojny światowej zaledwie jedna kobieta pełniła funkcję asesora prokuratorskiego i została nawet bohaterką bestsellera autorstwa Tadeusza Dołęgi-Mostowicza Prokurator Alicja Horn. Autor uczynił z niej postać $\mathrm{w}$ pełni profesjonalnej kobiety-prokuratora, próbującej połączyć własną naturę z męskim intelektem $\mathrm{w}$ celu podkreślenia głównego przesłania swojej powieści: istnieją zawody, których kobieta, choćby najlepiej przygotowana, nie jest $\mathrm{w}$ stanie dobrze wykonywać ${ }^{73}$.

\section{Wnioski}

Odzyskanie przez państwo polskie po 123 latach zaborów niepodległości przyniosło kobietom prawa wyborcze, które można uznać za punkt wyjścia $\mathrm{w}$ procesie pełnego zrównania praw publicznych obydwu płci. Kierunek przemian zmierzających do pełnego równouprawnienia kobiet wyznaczały normy uchwalonej w 1921 r. Konstytucji marcowej, wprowadzające zakaz różnicowania praw obywateli ze względu na płeć. Tworzone w II Rzeczypospolitej ustawy konsekwentnie realizowały zasadę równouprawnienia kobiet oraz zmieniały obowiązujące ustawodawstwo $\mathrm{w}$ kierunku usunięcia dyskryminujących kobiety przepisów byłych państw zaborczych. W kolejnych latach okresu międzywojennego kobiety uzyskały możliwość podejmowania pracy w charakterze urzędników państwowych, adwokatów, sędziów i prokuratorów. Kobiety zasiadały także we wszystkich parlamentach II Rzeczypospolitej i chociaż ich reprezentacja była skromna, to posłanki przyczyniły się do uchwalenia wielu postępowych ustaw regulujących ważne kwestie społeczne.

Wprawdzie organy ustawodawcze Polski międzywojennej stanęły na wysokości zadania i konsekwentnie uchwalały akty prawne przyznające kobietom pełnię praw politycznych, lecz sama litera prawa nie była w stanie przezwy-

Była nią Maria Hasińska, która po sześciu latach asesury otrzymała nominację na sędziego sądu grodzkiego w Łodzi. Orzekała tam w sprawach cywilnych, ale już w 1938 r. powierzono jej rozpatrywanie spraw karnych w sądzie grodzkim w Warszawie. M. Stypułkowska, op. cit., s. 147.

73 D. Kałwa, op. cit., s. 103-104. 
ciężyć konserwatywnej tradycji i zakorzenionych w polskim społeczeństwie stereotypów. Zdominowane przez mężczyzn władze publiczne unikały mianowania kobiet na ważniejsze stanowiska i tolerowały sprzeczne z postanowieniami Konstytucji praktyki zmierzające do ograniczenia udziału kobiet w życiu publicznym. Szczególnym przejawem naruszenia konstytucyjnej zasady równości praw kobiet i mężczyzn była obowiązująca na Górnym Śląsku ustawa celibatowa, u podstaw uchwalenia której legł szczególnie silny w społeczeństwie górnośląskim tradycyjny obraz kobiety jako matki i żony. Tego rodzaju niekonstytucyjnym praktykom sprzyjał brak organu powołanego do badania zgodności ustaw z Konstytucją oraz słabość polityczna środowisk kobiecych, które nie potrafiły zorganizować się w celu skutecznej obrony przysługujących im praw publicznych.

Formalna równość praw kobiet dotyczyła tylko sfery publicznej, gdyż wskutek oporu środowisk konserwatywnych popieranych przez Kościół katolicki nie udało się wprowadzić w życie zasady całkowitego równouprawnia kobiety i mężczyzny w prawie prywatnym. Tym bardziej należy docenić fakt uchwalenia w 1921 r. z inicjatywy środowisk kobiecych i przy aktywnym udziale posłanek ustawy likwidującej najdalej idące przejawy dyskryminacji kobiet zamężnych, zawarte $\mathrm{w}$ ustawodawstwie obowiązującym na terenie byłego zaboru rosyjskiego ${ }^{74}$. Główną przeszkodą na drodze ku pełnemu równouprawnieniu był utrwalony w społeczeństwie tradycyjny pogląd o dominującej pozycji i mężczyzny i związana z nim nieufność wobec nowej roli kobiety wykraczającej poza prowadzenie domu i wychowanie dzieci. Gruntowna zmiana świadomości społecznej wymagała czasu znacznie dłuższego niż dwudziestolecie wojenne, stąd na całkowite zrównanie praw kobiet i mężczyzn trzeba było poczekać aż do lat powojennych. Realizacja zasady równouprawnienia płci w Polsce Ludowej zakończyła się sukcesem zarówno na polu ustawodawczym, jak też $\mathrm{w}$ praktyce życia codziennego, lecz przebiegałaby znacznie trudniej bez dorobku II Rzeczypospolitej w dziedzinie formalnego zrównania pozycji prawnej kobiet i mężczyzn.

\section{Bibliografia}

\section{Akty prawne}

Dekret Tymczasowego Naczelnika Państwa z dnia 28 listopada 1918 r. o ordynacji wyborczej do Sejmu Ustawodawczego (Dziennik Praw Państwa Polskiego (Dz. P. P. P.) Nr 18 z 1918 r.)

74 Ustawa z dnia 1 lipca 1921 r. w przedmiocie zmiany niektórych przepisów obowiązującego w b. Królestwie Polskiem prawa cywilnego, dotyczących praw kobiet (Dz.U. Nr 64, poz. 397). 
Dekret Tymczasowego Naczelnika Państwa: o wyborach do rad miejskich na terenie dawnego Królestwa Kongresowego z 18 grudnia 1918 r. (Dz.P.P.P.) Nr 20, poz. 58).

Dekret Tymczasowego Naczelnika Państwa z Dnia 24 grudnia 1918 r. Statut tymczasowy Palestry Państwa Polskiego (Dz. Pr. P. P. 1918, Nr 22, poz. 75).

Dekret Tymczasowego Naczelnika Państwa z dnia 8 lutego 1919 r. o aplikacji sądowej (Dz. Pr. P. P. Nr 18, poz. 225).

Dekret Tymczasowego Naczelnika Państwa z 14 lutego 1919 r. o samorządzie miejskim (Dziennik Praw Państwa Polskiego 1919, Nr 13, poz. 140).

Ustawa z dnia 17 marca 1921 r. Konstytucja Rzeczypospolitej Polskiej (Dz. U. Nr 44, 267).

Ustawa z dnia 1 lipca $1921 \mathrm{r}$. w przedmiocie zmiany niektórych przepisów obowiązującego w b. Królestwie Polskiem prawa cywilnego, dotyczących praw kobiet (Dz.U. Nr 64, poz. 397).

Ustawa z dnia 17 lutego 1922 r. o państwowej służbie cywilnej (Dz. U. Nr 21, poz. 164).

Ustawa z dnia 29 marca 1926 r. w sprawie rozwiązania stosunku służby nauczycielskiej wskutek zawarcia przez nauczycielkę związku małżeńskiego (Dziennik Ustaw Śląskich 1926, Nr 8, poz. 12).

Rozporządzenie Prezydenta Rzeczypospolitej Polskiej z dnia 6 lutego 1928 r. prawo o ustroju sądów powszechnych (Dz. U. Nr 12, poz. 93).

Ustawa z dnia 23 marca 1933 r. o częściowej zmianie ustroju samorządu terytorialnego (Dz. U. Nr 35, poz. 294).

Rozporządzenie Prezydenta Rzeczypospolitej z dnia 28 października 1933 r. w sprawie zmiany ustawy z dnia 1 lipca 1926 r. o stosunkach służbowych nauczycieli i rozporządzenia Prezydenta Rzeczypospolitej Polskiej z dnia 6 marca 1928 r. w sprawie o kwalifikacjach zawodowych nauczycieli szkół powszechnych (Dz. U. Nr 85, poz. 600).

Ustawa z dnia 22 czerwca 1934 r. o stosunkach służbowych śląskich funkcjonariuszów publicznych (Dziennik Ustaw Śląskich Nr 18, poz. 37).

Ustawa konstytucyjna z dnia 23 kwietnia 1935 r. (Dz. U. Nr 30, poz. 227).

Ustawa z dnia 9 kwietnia 1938 r. o zmianie ustawy o stosunkach służbowych nauczycieli (Dz. U. Nr 27, poz. 243).

\section{Sprawozdania stenograficzne $\mathrm{z}$ posiedzeń sejmowych}

Sprawozdanie stenograficzne z 138 posiedzenia Sejmu Ustawodawczego w dniu 20 kwietnia $1920 \mathrm{r}$.

Sprawozdanie stenograficzne z 134 posiedzenia I Sejmu Śląskiego z 29 III 1926, łam 3. 


\section{Literatura}

Chojnowski A., Moralność i polityka. Kobiece lobby w Bezpartyjnym Bloku Wspótpracy $z$ Rządem, [w:] Kobieta i świat polityki, red. A. Żarnowska, A. Szwarc, Warszawa 1996.

Chojnowski A., Aktywność kobiet w życiu politycznym, [w:] Równe prawa i nierówne szanse. Kobiety w Polsce międzywojennej, red. A. Żarnowska, A. Szwarc, Warszawa 2000.

Chojnowski A., Kobiety i polityka w Drugiej Rzeczypospolitej, [w:] Kobieta i świat polityki, red. A. Żarnowska, A. Szwarc, Warszawa 1996.

Fuszara M., Kobiety w polityce, Warszawa 2007.

Gawin M., Głosy krytyczne w sprawie zawodowej kwestii kobiet 1918-1939, [w:] Kobieta i praca. Wiek XIX i XX, red. A. Żarnowska, A. Szwarc, Warszawa 2000.

Glimos-Nagórska A., Tradycjonalizm ślaski a równouprawnienie kobiet. Praca zawodowa i życie codzienne nauczycielek województwa śląskiego (1922-1939), [w:] Równe prawa i nierówne szanse. Kobiety w Polsce międzywojennej, Warszawa 2000.

Hass L., Aktywność wyborcza kobiet w pierwszym dziesięcioleciu Drugiej Rzeczypospolitej, [w:] Kobieta i świat polityki, red. A. Żarnowska, A. Szwarc, Warszawa 1996.

Historia państwa i prawa polskiego, red. J. Bardach, B. Leśnodorski, M. Pietrzak, Warszawa 1996.

Kałwa D., Kobieta aktywna w Polsce międzywojennej. Dylematy środowisk kobiecych, Kraków 2001.

Kondracka M., Kobiety na uniwersytetach, [w:] Równe prawa i nierówne szanse. Kobiety $w$ Polsce międzywojennej, red. A. Żarnowska, A. Szwarc, Warszawa 2000.

Krukowski S., Konstytucja Rzeczypospolitej Polskiej z 1921 r., [w:] Konstytucje Polski. Studia monograficzne z dziejów polskiego konstytucjonalizmu, red. M. Kallas, Warszawa 1990.

Ludwikowski R., Prawo konstytucyjne porównawcze, Torun 2000.

Łuszkiewicz G., Kobiety w samorzadzie miejskim drugiej Rzeczypospolitej. Próba portretu zbiorowego, [w:] Kobieta i świat polityki, red. A. Żarnowska, A. Szwarc, Warszawa 1996.

Materniak-Pawłowska M., Zawód sędziego w Polsce w latach 1918-1939, „Czasopismo Prawno-Historyczne" 2011, nr 1.

Materniak-Pawłowska M., Adwokatura w II Rzeczypospolitej. Zagadnienia prawno-ustrojowe, Poznań 2009.

Milewski Z., Zanim kobieta została adwokatem, „Palestra” 2002, nr 1-2.

Mohyluk M., Prawo o ustroju sądów powszechnych w pracach Komisji Kodyfikacyjnej II Rzeczypospolitej, Białystok 2004.

Niewiadomska-Cudak M., Kobiety w polskich organach kolegialnych w latach 1919-2011, Toruń 2013.

Nowak A., Wójcik M., Kobieta w rodzinie w II Rzeczypospolitej, Katowice 2000. 
Perkowska U., Studentki Uniwersytetu Jagiellońskiego w latach 1894-1939, [w:] Kobieta i kultura, red. A. Żarnowska, A. Szwarc, Warszawa 1996.

Pietrzak M., Sytuacja prawna kobiet w Drugiej Rzeczypospolitej, [w:] Równe prawa $i$ nierówne szanse. Kobiety w Polsce międzywojennej, red. A. Żarnowska, A. Szwarc, Warszawa 2000.

Piłsudska A., Wyznania gorszycielki, oprac. A. Tuszyńska, Warszawa 1992.

Podkowski M., Udział kobiet w parlamentach Drugiej Rzeczypospolitej, [w:] Pozycja prawna kobiet w dziejach, red. S. Rogowski, Wrocław 2010.

Stypułkowska M., Trudna droga kobiet do wykonywania zawodów prawniczych, „Palestra” 1994, nr 9-10.

Śliwa M., Kobiety w parlamencie Drugiej Rzeczypospolitej, [w:] Kobieta i świat polityki, red. A. Żarnowska, A. Szwarc, Warszawa 1996.

Śliwa M., Udział kobiet w wyborach $i$ ich działalność parlamentarna, [w:] Równe prawa $i$ nierówne szanse. Kobiety w Polsce międzywojennej, red. A. Żarnowska, A. Szwarc, Warszawa 2000.

Tarnowska A., Narodziny trzeciej „płci”. Kobieta w prawie publicznym II RP, [w:] Płeć $w \dot{z} y c i u$ publicznym, red. M. Jeziński, M. Wincławska, B. Brodzińska, Toruń 2009.

Wanatowicz W., Ludność naptywowa na Górnym Śląsku w latach 1922-1939, Katowice 1982.

Wapiński R., Kobiety $i$ życie publiczne - przemiany pokoleniowe, [w:] Równe prawa $i$ nierówne szanse. Kobiety w Polsce międzywojennej, red. A. Żarnowska, A. Szwarc, Warszawa 2000.

Wawrzykowska-Wierciochowa D., Od prządki do astronautki, Warszawa 1963.

Żarnowski J., Kobiety w strukturze społeczno-zawodowej Polski międzywojennej, [w:] Równe prawa i nierówne szanse. Kobiety w Polsce międzywojennej, red. A. Żarnowska, A. Szwarc, Warszawa 2000. 